(C) Д.Б. Домбровський, В.В. Савін, Ю.Р. Пшиборовська, 2020

УДК 616.137.83-004.6-005.4-089.843-031:611.013.68-032

\title{
Клініко-функціональні аспекти трансплантації клітин кордової крові у хворих із дистальним ураженням артерій нижніх кінцівок
}

\author{
Д.Б. Домбровський, В.В. Савін, Ю.Р. Пшиборовська
}

Буковинський державний медичний університет, кафедра хірургї №1; Чернівецька обласна клінічна лікарня, відділення хірургії судин, Чернівиі

\section{Реферат}

Вступ. В Україні хронічні облітеруючі захворювання артерій нижніх кінцівок займають більше $20 \%$ серед всіх уражень серцево-судинної системи.

Мета дослідження. Провести порівняльний аналіз клінічного стану пацієнтів із дистальним ураженням артеріального русла при використанні стандартної консервативної терапії із застосуванням трансплантації клітин кордової крові та без неї.

Матеріали та методи. Дослідну групу формували пацієнти з проявами хронічної ішемії нижніх кінцівок на тлі облітеруючого атеросклерозу, яким проводилася трансплантація клітин кордової крові в поєднанні 3 консервативною терапією. До групи контролю ввійшли пацієнти з облітеруючим атеросклерозом та дистальним ураженням судин нижніх кінцівок, що отримували базовий курс консервативної терапії. Для визначення якості життя до та після трансплантації клітин кордової крові ми використали низку уніфікованих опитувальників, за допомогою яких визначали дистанцію переміжної кульгавості та проводили суб'єктивну оцінку рівня особистого благополуччя пацієнтів. Для аналізу стану мікроциркуляції в ішемізованій кінцівці ми використали метод лазерної доплерівської флоуметрії.

Результати досліджень та їх обговорення. Після трансплантації клітин кордової крові відзначається покращення загального стану хворих, зменшення ступеня ішемії за класифікацією Рутерфорда, збільшення дистанції та швидкості безбольової ходьби протягом перших 3 місяців на 5-10\%, і у 1,3 разу через 12 місяців, порівняно 3 контрольною групою. Покращення мікроциркуляторних показників лазерної доплерівської флоуметрії відзначається починаючи 3 кінця першого і до 12 місяця після трансплантації, що свідчить про поліпшення стану мікрогемодинаміки.

Висновки. Використання трансплантації клітин кордової крові з метою стимуляції ангіогенезу дозволяє отримати тривалий позитивний клінічний ефект, який проявляється у вигляді збільшення дистанції та швидкості безбольової ходьби, покращення працездатності, поліпшення особистого благополуччя пацієнтів у фізичній, психологічній та соціально-економічномічній сфері, що корелює з даними лазерної доплерівської флоуметрії та розширює можливості успішного лікування хворих з хронічною ішемією нижніх кінцівок на тлі облітеруючого атеросклерозу.

Ключові слова: облітеруючий атеросклероз, хронічна ішемія нижніх кінцівок, трансплантація, кордова кров.

Clinical and functional aspects of cord blood cell transplantation in patients with distal lesions of the lower limb arteries Dombrovsky D.B., Savin V.V., Pshyborovska Yu.R.

Bukovina State Medical University, Department of Surgery №1;

Regional Clinical Hospital, Department of Vascular Surgery, Chernivtsi

Abstract

Purpose of work. Conduct comparative analysis of the clinical condition of patients with distal lesions of the arterial bed using standard conservative therapy with and without cord blood cell transplantation.

Materials and methods. The study group was formed of patients with manifestations of chronic ischemia of the lower limb against obliterating atherosclerosis, who underwent transplantation of cord blood cells in combination with conservative therapy. The control group included patients with distal lesions of the lower limb vessels with obliterating atherosclerosis receiving a basic course of conservative therapy. To determine the quality of life characteristics before and after cord blood cell transplantation, we used a number of standardized questionnaires, with which we determined the distance of intermittent claudication and subjectively assessed the level of personal well-being of patients. For a detailed of the state of microcirculation in the ischemic limb, we used the laser doppler flowmetry method.

Results and discussion. After transplantation of cord blood cells, an improvement in the general condition of the patients was observed, a decrease in the degree of ischemia to Rutherford's classification, an increase in the distance and the rate of painless walking by 5-10\% during the first 3 months, and 1.3 times in 12 months, compared with the control group are noted. Improvement of microcirculatory indicators of laser doppler flowmetry was obserwed from the end of the first and up to 12 months after transplantation, which indicates an improvement in the state of microhemodynamics.

Conclusion. The use of cord blood cell transplant for the stimulation of angiogenesis allows to obtain a long lasting positive clinical effect, which is manifested in the form of an increase the distance and speed of pain-free walking, improving performanse, improving the personal well-being of patients in the physical, psychological and socio-economic sphere, which correlates with laser doppler flowmetry and expands the possibilities of successful treatment of patients with chronic lower limb ischemia against the background of obliterating atherosclerosis.

Key words: obliterating atherosclerosis, chronic lower limb ischemia, transplantation, cord blood.

Вступ. В Україні хронічні облітеруючі захворювання артерій нижніх кінцівок займають більше
$20 \%$ серед всіх уражень серцево-судинної системи $[1,2,3]$. Смертність серед пацієнтів, які мають по- 
чаткові клінічні прояви даної патології у вигляді переміжної кульгавості становить 3-5\% за рік, а при наявності критичної ішемії нижніх кінцівок смертність підвищується до $20 \%$ за рік $[4,5]$.

Частота ампутацій при судинній патології як в Україні, так і за ії межами досягає 59\%, а показник летальності доходить до 48\%. Летальність залишається головною проблемою в цій групі пацієнтів: $30-40 \%$ з них живуть менше 5 років $[6,8]$.

При відсутності «приймаючого» судинного русла або наявності протипоказань до реконструктивної операції єдиним способом залишається ампутація або непряма реваскуляризація, що сприяє посиленню компенсаторних можливостей мікроциркуляторного русла внаслідок збільшення щільності та загальної площі капілярної мережі [7].

Таким чином, проблема лікування хворих з дистальним ураженням артерій нижніх кінцівок одна 3 найбільш актуальних у судинній хірургії, а іiі вирішення дозволить не тільки зберегти кінцівку неоперабельним пацієнтам, а й істотно поліпшити їх якість життя.

У світі існує достатня кількість рандомізованих досліджень 3 використанням стовбурових клітин. Їх різноманітність, ступінь технічної складності та травматичності відомі досить давно та широко обговорюються в літературі.

Joshua M. Hare et all. [9] у 2017 році опублікували результати рандомізованого дослідження POSEIDON-DCM Trial порівняння безпечності та ефективності аутологічних і алогенних мезенхімальних стовбурових клітин кісткового мозку в лікуванні хронічної неішемічної дилятаційної кардіоміопатії, що проводилося в Госпіталі університету Маямі, США з 2011 по 2015 роки.

У 2018 році вчені Університету Дюка (Duke University) та Хьюстонського методистського неврологічного інституту (Houston Methodist Neurological Institute) (США) оприлюднили peзультати 1 фази багатосайтового відкритого про- спективного клінічного випробування, що вивчало безпеку трансплантації клітин кордової крові пацієнтам, які перенесли ішемічний інсульт. У ході дослідження доведено, що дана методика є безпечною, добре переносимою та можливою. Наразі ініційовано більш масштабне рандомізоване плацебо-контрольоване подвійне сліпе дослідження 2 фази для оцінки здатності клітин кордової крові до покращення функціональних результатів у хворих на гострий ішемічний інсульт [10].

Мета дослідження. Провести порівняльний аналіз клінічного стану пацієнтів 3 дистальним ураженням артеріального русла при використанні стандартної консервативної терапії із застосуванням трансплантації клітин кордової крові та без неї.

Матеріали та методи. У дослідну групу нами було відібрано 16 пацієнтів, які перебували на стаціонарному лікуванні у відділенні хірургії судин ОКУ «Чернівецька обласна клінічна лікарня» - 12 чоловіків (75\%) та 4 жінки (25\%) з проявами хронічної ішемії нижніх кінцівок на тлі облітеруючого атеросклерозу, яким проводилася трансплантація клітин кордової крові в поєднанні 3 консервативною терапією. До групи контролю ввійшли 11 пацієнтів: 9 чоловіків (82\%) та 2 жінки (12\%) 3 облітеруючим атеросклерозом та дистальним ураженням судин нижніх кінцівок, що отримували базовий курс консервативної терапії в середньостатистичних дозах.

Наявність хронічної ішемії у пацієнтів підтверджувалася за допомогою інструментальних методів дослідження та наявністю відповідної клінічної симптоматики: біль у нижній кінцівці, що 3'являється під час фізичного навантаженні або в стані спокою, наявність трофічних порушень м'яких тканин стопи або без них, довготривалий перебіг захворювання. Характер прояву клінічної симптоматики був різним залежно від ступеня ішемії кінцівки (табл. 1).

Таблиця 1

Розподіл хворих за ступенем ішемії нижніх кінцівок

\begin{tabular}{|c|c|c|c|c|c|c|}
\hline \multirow{2}{*}{$\begin{array}{c}\text { За Фонтей- } \\
\text { ном }\end{array}$} & \multirow{2}{*}{\multicolumn{2}{|c|}{ Симптоми }} & \multicolumn{2}{|c|}{ По Рутерфорду } & \multirow{2}{*}{$\begin{array}{c}\text { Дослідна } \\
\text { група }(\mathrm{n}=9)\end{array}$} & \multirow{2}{*}{$\begin{array}{l}\text { Контрольна } \\
\text { група }(\mathrm{n}=11)\end{array}$} \\
\hline & & & Ступінь & Клас & & \\
\hline I & \multicolumn{2}{|c|}{ безсимптомний перебіг } & 0 & 0 & - & - \\
\hline IIa & $\begin{array}{c}\text { кульгавість } \\
>200 \text { м }\end{array}$ & легка кульгавість & I & 1 & - & - \\
\hline \multirow[t]{2}{*}{ IIб } & \multirow{2}{*}{$\begin{array}{c}\text { кульгавість } \\
<200 \text { м }\end{array}$} & $\begin{array}{c}\text { помірна кульга- } \\
\text { вість }\end{array}$ & I & 2 & - & - \\
\hline & & тяжка кульгавість & $\mathrm{I}$ & 3 & - & 2 \\
\hline III & \multicolumn{2}{|c|}{ біль у спокої } & II & 4 & 11 & 5 \\
\hline \multirow{2}{*}{ IV } & \multirow{2}{*}{$\begin{array}{c}\text { некроз } \\
\text { та ішемічні } \\
\text { виразки }\end{array}$} & $\begin{array}{c}\text { незначне ушкод- } \\
\text { ження тканин }\end{array}$ & III & 5 & 5 & 4 \\
\hline & & $\begin{array}{c}\text { значне ушкоджен- } \\
\text { ня тканин }\end{array}$ & IV & 6 & - & - \\
\hline
\end{tabular}


Із метою детальнішої оцінки ступенів важкості ішемії нижніх кінцівок ми використали класифікацію за R.B. Rutherford [11], адже тут виділені в окремі самостійні пункти різні за ступенем вираження варіанти переміжної кульгавості. Вона грунтується на функціональних даних артерій нижніх кінцівок і в повній мірі відображає клінічний стан нижніх кінцівок, включаючи характеристику periонарної гемодинаміки.

Критеріями відбору пацієнтів для дослідження були: дистальне ураження артерій нижніх кінцівок, неможливість виконання «прямих» реконструктивних операцій, належність пацієнтів 4 та 5 класу за Рутерфордом (III та IV ступінь ішемії за Фонтейном 3 незначними трофічними розладами), негативні тести на онкомаркери та відсутність онкологічної патології в анамнезі. Критерії виключення: можливість виконання реконструктивної операції на магістральних артеріях, належність до 6 класу за Рутерфордом (IV ступінь ішемії за Фонтейном 3 вираженими трофічними розладами), позитивні тести на онкомаркери чи обтяжений онкологічний анамнез, цукровий діабет. Наявність у хворих іншої супутньої патології дозволяла пацієнтам брати участь у формуванні дослідної групи.

Iз метою покращення реваскуляризації пацієнтам групи дослідження проводили трансплантацію клітин кордової крові на тлі призначеної консервативної терапії. Клітинний трансплантат отримували 3 банку пуповинної крові ТОВ «Інститут клітинної терапії» згідно 3 договором. Суспензію вводили в ішемізовану кінцівку за допомогою довгої тонкої канюлі підфасціально по медіальній та латеральній поверхні гомілки за розробленою в ході дослідження методикою (Патент України №13117 від 10.01.2019 р). Загальна кількість введеної суспензії, що містила стовбурові клітини кордової крові, в одну кінцівку становила $50 \pm 5$ мл (вміст ядровмісних клітин - від $47 \times 10^{6}$ до $356 \times 10^{6}$, життєздатність клітин - не менше $87 \pm 5 \%$ від початкової).

Для оцінки ефективності трансплантації клітин кордової крові ми використовували уніфікований опитувальник Walking Impairment Questionnaire (WIQ), який рекомендований як специфічний опитувальник для пацієнтів із переміжною кульгавістю з визначенням дистанції безболісної ходьби та можливу швидкість ходьби у пацієнтів із дистальним ураженням артерій нижніх кінцівок.

Додатково проводилось опитування для визначення "Індексу якості життя" ("Quality of Life Index”, Spitzer та співавт.), критеріями якого $\epsilon$ оцінка пацієнтом рівня особистого благополуччя у фізичному, психічному та соціально-економічному відношенні. Максимальна кількість балів, що міг набрати пацієнт, складала 10 балів, мінімальна 0 балів.

Згідно $з$ рекомендаціями щодо стандартизації (European Contact Dermatitis Society, від 1994) нами проведено аналіз показників лазерної доплерівської флоуметрії у хворих із хронічною ішемією кінцівок, де визначали гемодинамічний тип мікроциркуляції та навели декілька показників, які, на нашу думку, досить яскраво характеризують стан мікрогемодинаміки.

Результати досліджень та їх обговорення. У всіх пацієнтів дослідної групи після трансплантації клітин кордової крові спостерігали позитивну клінічну динаміку. Протягом першого місяця після клітинної трансплантації хворі виявили поступове покращення самопочуття, зменшувався, а надалі був відсутнім біль у спокої, зменшувалися трофічні розлади та загоювалися крайові некрози пальців, поступово збільшувалась дистанція та швидкість безбольової ходьби. Через 3 міс після клітинної трансплантації, окрім покращення місцевого статусу, простежувалося покращення загального стану, збільшились працездатність та загальна активність. Стан пацієнтів через 6 місяців після клітинної трансплантації: усі пацієнти працездатні, ведуть активне соціальне та побутове життя.

Через 12 місяців після трансплантації чітко прослідковується перехід пацієнтів у групу з нижчим ступенем ішемії, що яскраво наведено в таблиці (табл. 3).

Динаміка ступеня ішемії кінцівки після трансплантації

Таблиця 3

\begin{tabular}{|c|c|c|c|}
\hline $\begin{array}{c}\text { Ступінь хронічної ішемії } \\
\text { за Рутерфордом }\end{array}$ & Клас & $\begin{array}{c}\text { До клітинної } \\
\text { трансплантації }\end{array}$ & $\begin{array}{c}\text { Через 12 міс після клітинної } \\
\text { трансплантації }\end{array}$ \\
\hline 0 & 0 & - & - \\
\hline I & 1 & - & 2 \\
\hline I & 2 & - & 5 \\
\hline I & 3 & - & 3 \\
\hline II & 4 & 11 & - \\
\hline III & 5 & 5 & - \\
\hline
\end{tabular}

Дистанція та швидкість безбольової ходьби пацієнтів збільшувалася на 5-10\% протягом перших 3 місяців, а через 12 місяців - у 1,3 разу, порівняно з групою контролю (рис. 1). 


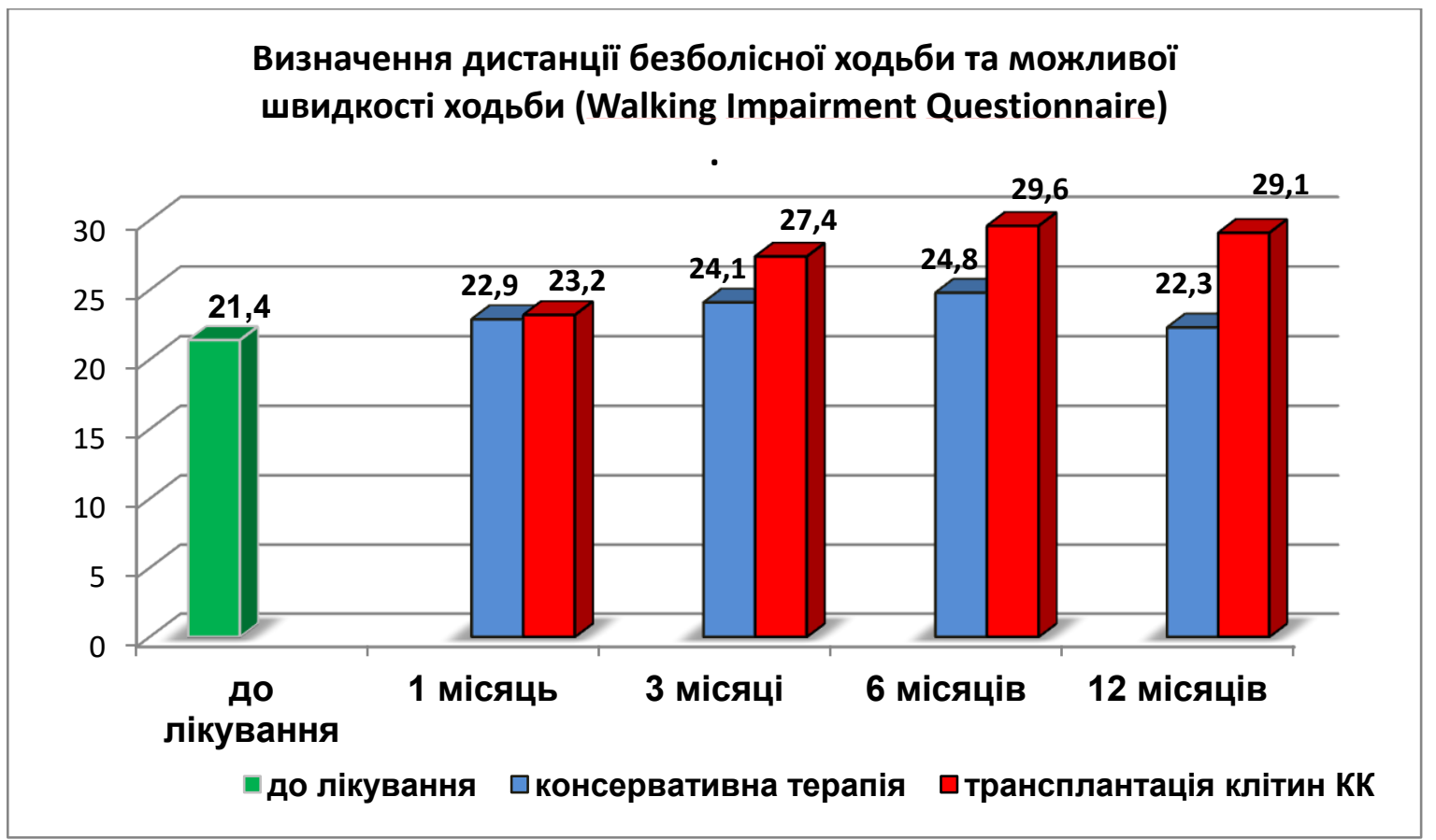

Рис. 1. Визначення дистанції безболісної ходьби та можливої швидкості ходьби в динаміці.

Прогресуюче збільшення індексу якості життя спостерігалося через 6 місяців після трансплантації, а через 1 рік даний показник збільшився на
18,2\% порівняно з аналогічним показником групи контролю (рис. 2).

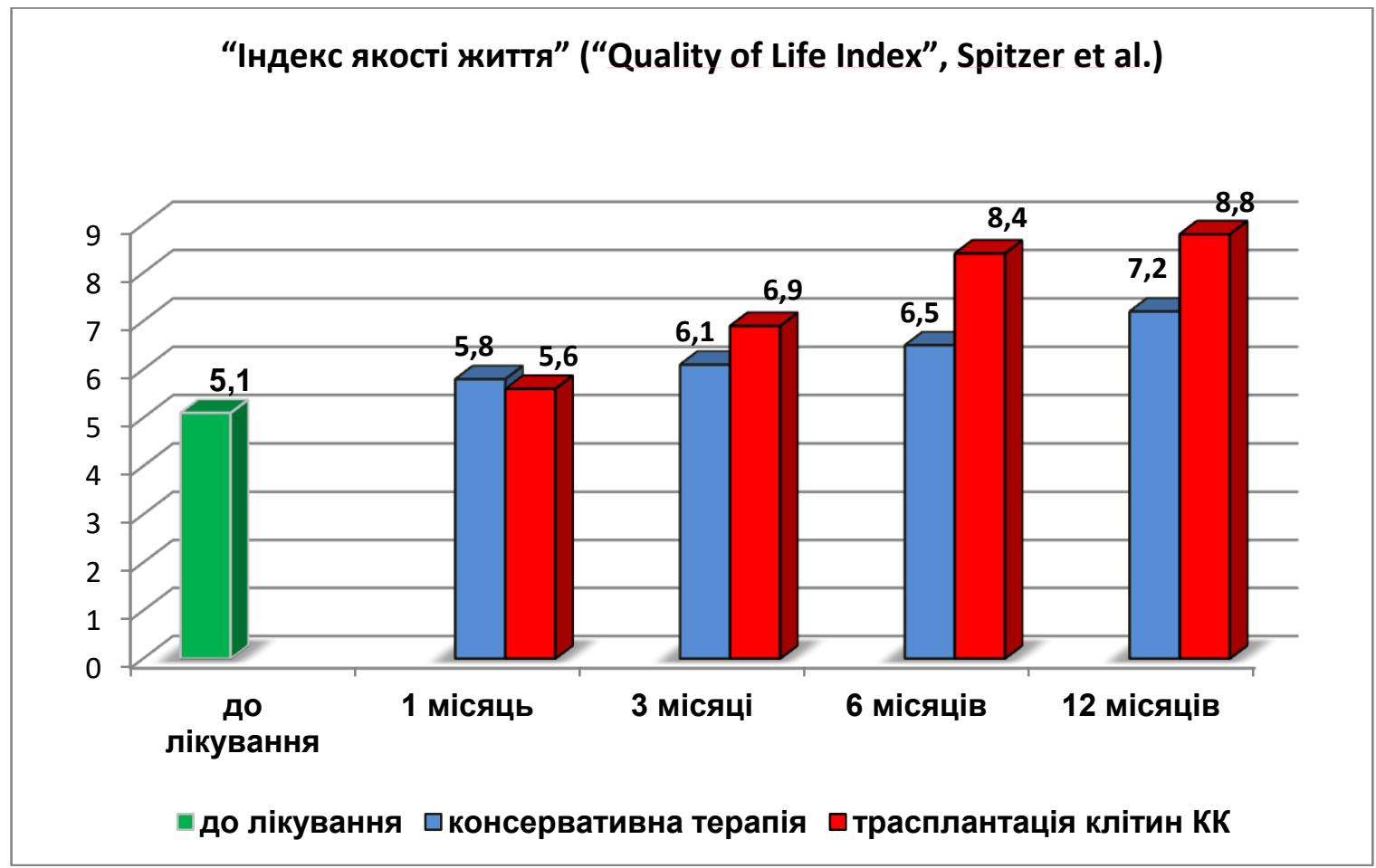

Рис. 2. Визначення індексу якості життя в динаміці.

При проведенні лазерної доплерівської флолуметрії ми досліджували тип гемодинаміки, показник мікроциркуляції на фоновому запису (Мф), резерв капілярного кровотоку оклюзивної проби (РККо) та показника мікроциркуляції І-го пальця стопи (ПМ). Аналізуючи показники до лікування відзначено, що значення Мф з передпліччя лівої руки було достовірно більшим $(7,02 \pm 1,04)$, що вказує на зміни в судинному руслі порівняно 3 нормою (рис. 3). 


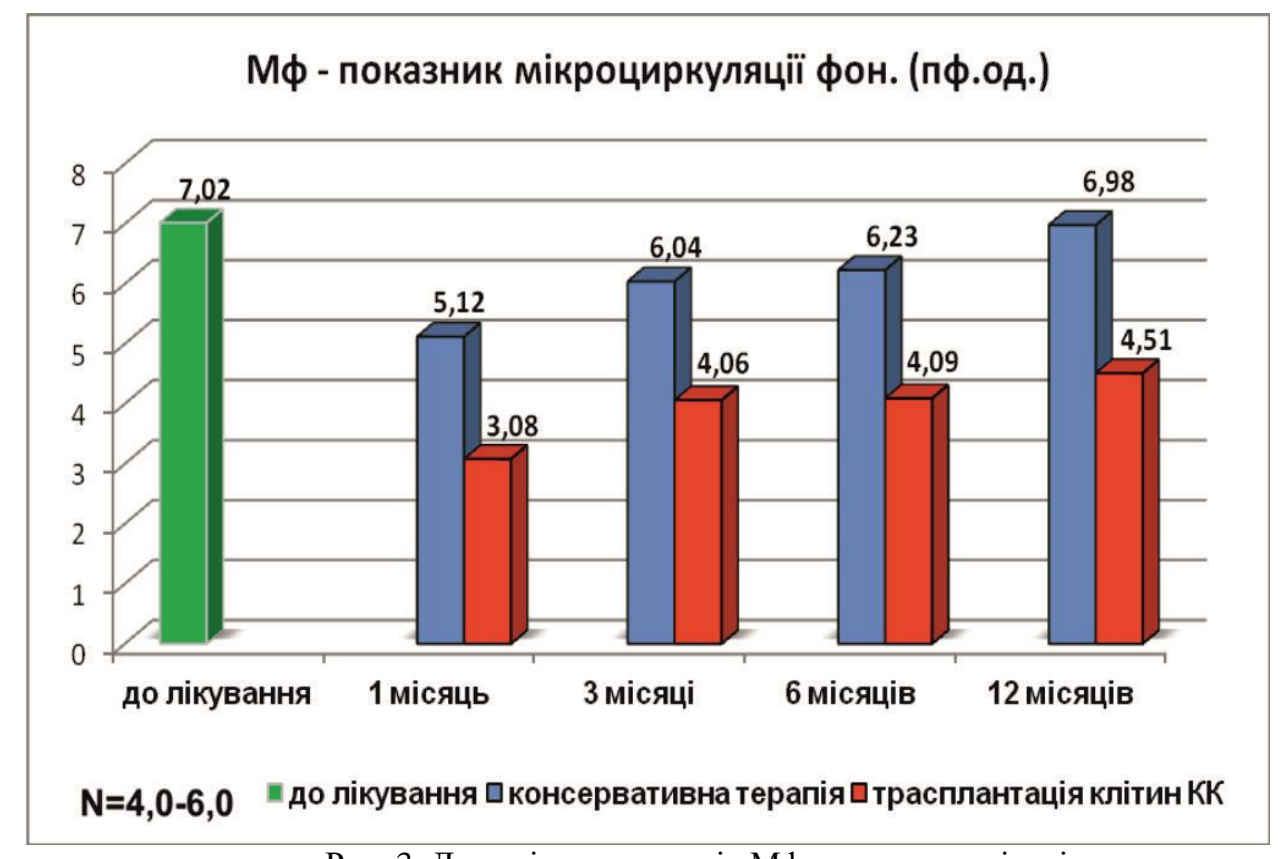

Рис. 3. Динаміка показників Мф у групах пацієнтів.

Через 1 місяць після трансплантації у дослідній групі визначається достовірне зменшення фонового показника мікроциркуляції, а через 3 місяці й надалі можна відзначити його нормалізацію.

У контрольній групі через 1 місяць після консервативної терапії спостерігається зниження даного показника до нормального рівня, проте після 3 місяців і надалі його значення підвищується до початкового рівня.

Також можемо бачити, що після трансплантації клітин кордової крові спостерігається покращення мікроциркуляторних показників, які відображаються рівнем РККо, починаючи з кінця першого і до 12 місяця (рис. 4). Ці зміни свідчать про поліпшення стану мікрогемодинаміки внаслідок покращення венозного відтоку, а також поліпшення ендотелій-залежної вазодилатації в дослідній групі. У пацієнтів групи контролю показники РККо через 1 місяць мали тенденцію до зростання, однак через 1 рік наближалися до початкових значень, що вказує на нетривалий та недостатній ефект стандартної консервативної терапії.

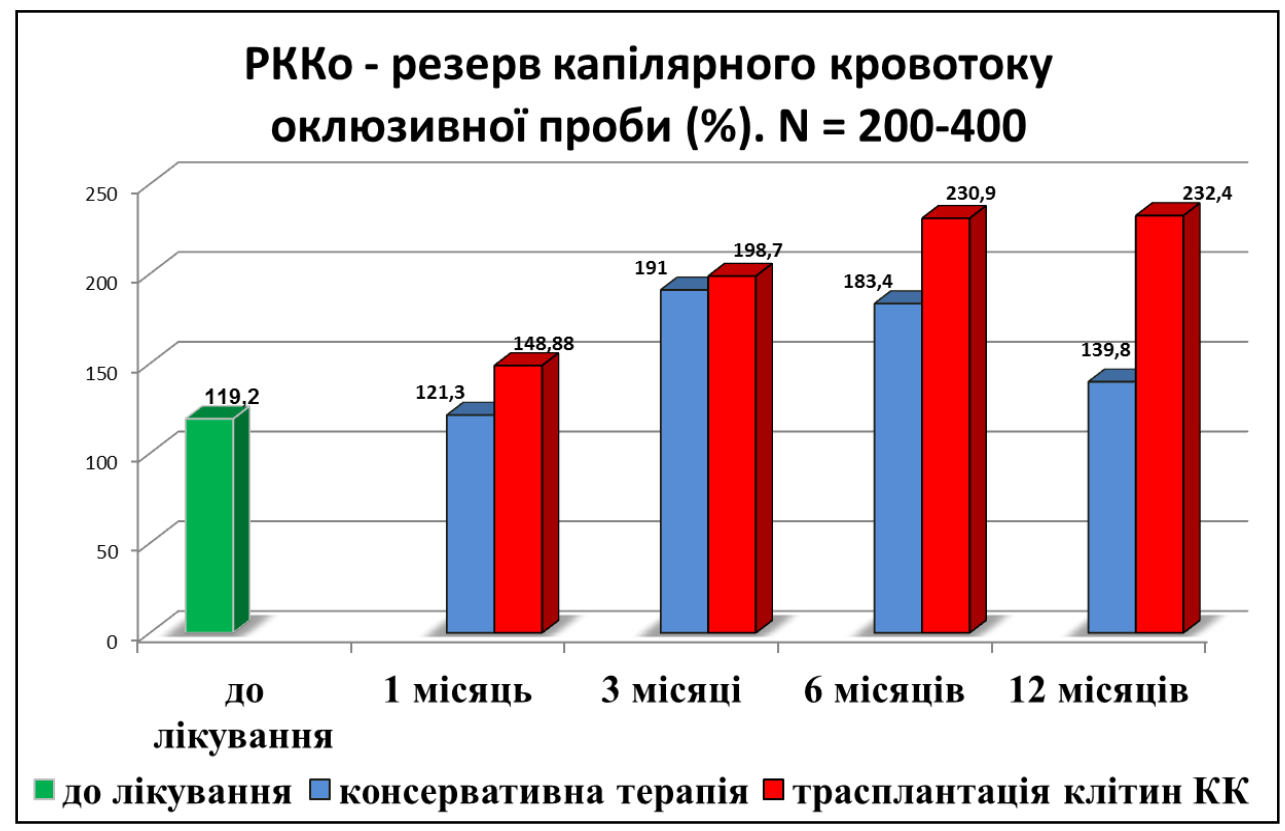

Рис. 4. Динаміка показників РККо у групах пацієнтів.

Крім того, після трансплантації клітин кордової крові виявлено стійку тенденцію до зростання показника мікроциркуляції І-го пальця стопи, при цьому, починаючи з 3 місяця і надалі, досліджуваний показник не відрізнявся від норми (рис. 5). 


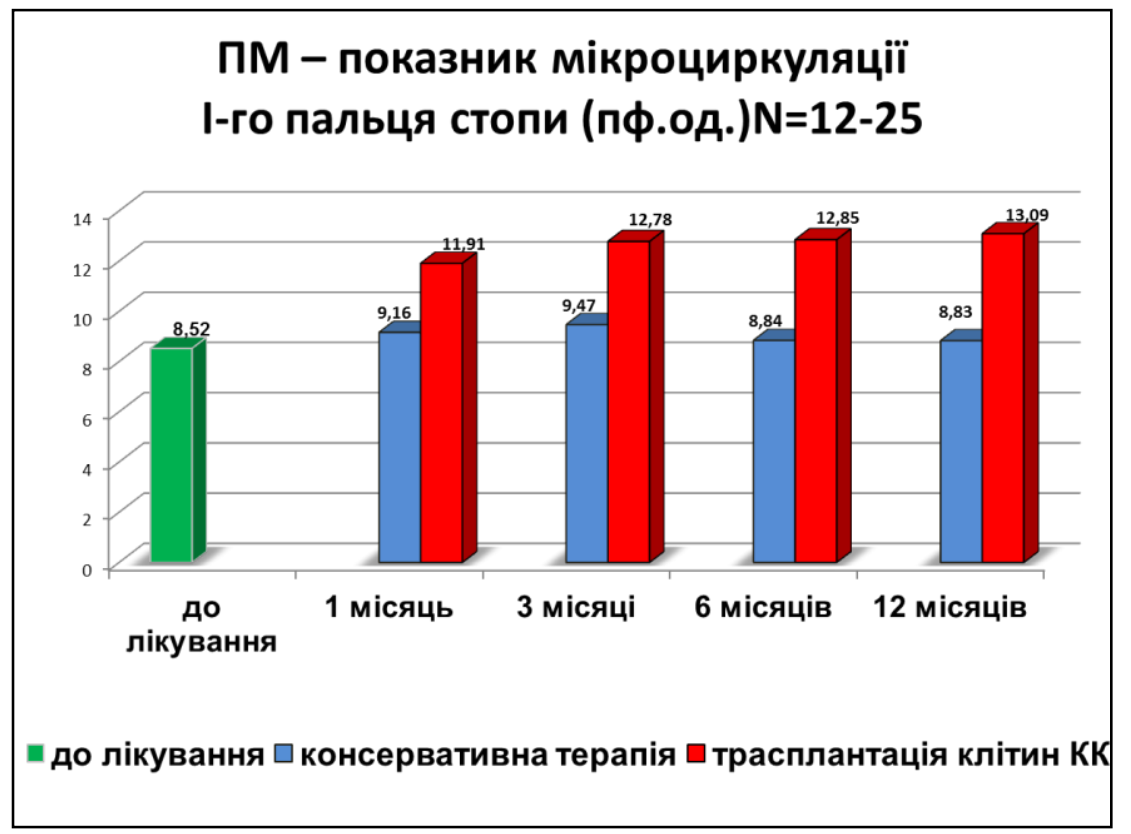

Рис. 5. Динаміка показника мікроциркуляції у групах пацієнтів.

У пацієнтів групи контролю на початку дослідження спостерігалося незначне покращення показників кровообігу. Однак наприкінці дослідження вони наближалися до початкових даних.

Висновки. Трансплантація стовбурових клітин кордової крові призводить до активації компенсаторно-відновної реакції в ішемізованій м'язовій тканині та стимуляції процесів ангіогенезу.
Завдяки застосуванню методу непрямої реваскуляризації шляхом трансплантації клітин кордової крові, можна отримати тривалий позитивний клінічний ефект, який проявляється у вигляді збільшення дистанції та швидкості безбольової ходьби, покращенні працездатності, поліпшенні особистого благополуччя пацієнтів у фізичній, психологічній та соціально-економічномічній сфері, що корелює 3 даними лазерної доплерівської флоуметрії.

Інформація про конфлікт інтересів. Автори заявляють про відсутність конфлікту інтересів при виконанні наукового дослідження та підготовці даної статті.

Інформація про фінансування. Автори гарантують, що вони не отримували жодних винагород у будь-якій формі, здатних вплинути на результати роботи.

Особистий внесок кожного автора у виконання роботи:

Домбровський Д.Б. - розробка концепції і дизайну дослідження, аналіз отриманих даних, редагування, статистична обробка даних;

Савін В.В. - збір матеріалу дослідження, розробка дизайну дослідження, аналіз отриманих даних;

Пшиборовська Ю.Р. - збір матеріалу дослідження, аналіз отриманих даних, підготовка тексту статті.

\section{Список використаної літератури}

1. Казаков Ю.И. Система оценки состоятельности русла оттока для определения возможности выполнения бедренно-подколенного шунтирования в изолированный артериальный сегмент у больных с критической ишемией / Ю.И. Казаков, И.Б. Лукин // Кардиология и сердечно-сосудистая хирургия. 2014. Т. 7 , № 5. С. 30-34.

2. Новиков Ю.В. Новый взгляд на ангиосомную теорию с точки зрения микроциркуляции / Ю.В. Новиков, А.А. Фомин, Д.Р. Першаков // Тромбоз, гемостаз и реология. 2015. №1. С. 36-41.

3. Питык А.И. Оценка риска неблагоприятного исхода после реваскуляризации нижних конечностей у больных при критической ишемии их тканей / А.И. Питык // Клінічна хірургія. 2014. № 8. С. 45-48.

4. Патогенетичне обгрунтування тактики хірургічного лікування критичної ішемії нижніх кінцівок при дистальних формах атеросклерозу / В.І. Русин, В.В. Корсак, В.В. Русин [та ін.] // Науковий вісник Ужгородського університету. Серія Медицина. 2015. № 1. С. 163-167.

5. Результаты гибридных реконструкций поверхностной бедренной артерии у больных с облитерирующим атеросклерозом сосудов нижних конечностей / А.В. Быковский, А.С. Иванов, Д.Н. Майстренко [и др.] // Вестник национального медико-хирургического центра им. Н.И. Пирогова. 2014. Т. 9, №1. С. 141-143.

6. Морфологічні та імуногістохімічні особливості дезоблітерованих стегнових артерій і підшкірних вен пацієнтів з облітеруючим атеросклерозом судин нижніх кінцівок в умовах розвитку хронічної критичної ішемії / І.С. Шпонька, О.Л. Ткачук, О.І. Гудз [та ін.] // Патологія. 2013. № 3. С. 38-42. 
7. Бедренно-подколенное шунтирование свободным аутовенозным трансплантатом ниже щели коленного сустава в лечении критической ишемии нижних конечностей / Б.С. Суковатых, Л.Н. Беликов, М.Б. Суковатых [и др.] // Новости хирургии. 2015. Т. 23, № 6. С. 637-643.

8. Beyersdorf F, Schlensak C. Controlled reperfusion after acute and persistent limb ischemia // Semin. Vas. Surg. 2009. Vol. 22 №52-57.

9. Joshua M. Hare, Darcy L. DiFede, Angela C. Rieger et al. Randomized Comparison of Allogeneic Versus Autologous Mesenchymal Stem Cells for Nonischemic Dilated Cardiomyopathy: POSEIDON-DCM Trial // J. Am. Coll. Cardio.2017. Vol. 69. №5. P. 538-540.

10. Daniel T. Laskowitz, Ellen R. Bennett, Rebecca J. Durham et al. Allogeneic Umbilical Cord Blood Infusion for Adults with Ischemic Stroke: Clinical Outcomes from a Phase I Safety Study //Stem Cells Transl Med. 2018. Vol. 7. №7. P. 521-529.

11. Rutherford, R. B. Standards for evaluating and reporting the results of surgical and percutaneous therapy for peripheral arterial disease / R. B. Rutherford, G. J. Becker // J. Vasc. Intervent. Radiol. 1991, № 2. P. 169-174.

Стаття надійшла до редакції: 17.02.2020 p. 